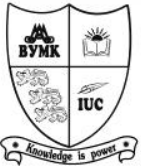

European Journal of Tourism Research

http://ejtr.vumk.eu

\title{
Developing a new typology for a behavioural classification of stakeholders using the case of tourism public policy planning in the snow sports industry
}

Paula Tomsett ${ }^{1 *}$ and Michael Shaw ${ }^{2}$

Received: 16/09/2013 Accepted: 24/04/2014

\footnotetext{
1 I-Shou University, International College, Department of International Business Administration, Kaohsiung, Taiwan ROC, Email: ptomsett@isu.edu.tw, Phone: +88676577711 ext. 8714

2 Director, Alpine Research Services and Lynx Research Group, Doncaster, Australia, Email: mike@lynxgroup.com.au, Phone: +86676567783

* Corresponding author
}

\begin{abstract}
Stakeholders have been broadly described as those people or groups with an interest in the outcomes of the actions taken by others, which includes actions by commercial businesses, not-forprofit organizations, and those of all levels of government as well as their delegated representatives. In considering their role the types and classification of stakeholders has become increasingly important to the efficient management of the public policy planning process, particularly in the tourism industry with its very diverse stakeholder population. In recent decades research on stakeholders in public policy making has been described in detail (through studies of attributes, interests, and influences) and has sought to categorize stakeholders (especially in identifying who should be a stakeholder and who is a genuine stakeholder) to better manage the consultative process involved. Using the process of constructing a strategic plan for the government controlled ski resorts in the State of Victoria (Australia) which involved substantial involvement from the public, businesses, property lessees and skiing enthusiasts, this paper reviews the utility of currently used stakeholder classification schema from both a theoretical and practical viewpoint and posits that a better approach to understanding differences would consider the behavioural variations between the stakeholder groups as they participate in the consultative phases of the process. It concludes that public policy managers can improve their understanding of potential stakeholder responses and proactively engage these people and groups in the public policy planning process by understanding the impact of the outcomes and nurturing their different levels of involvement and on-going support. This can be expected to improve acceptance and support of final policy decisions that are made, especially when difficult compromises between alternatives are required.
\end{abstract}

(C) 2015 International University College. All rights reserved

Keywords: stakeholders, tourism plans, public policy, stakeholder classification, snow sports

Citation: Tomsett, P. and Shaw M. (2015) Developing a new typology for a behavioural classification of stakeholders using the case of tourism public policy planning in the snow sports industry. European Journal of Tourism Research 9, pp. 115-128 
Developing a new typology for a behavioural classification of stakeholders using the case of tourism public policy planning in the snow sports industry.

\section{Introduction}

Stakeholders, commonly perceived as a homogeneous section of the population, are simply described as people, groups or organizations with any interest or involvement in 'something' such as the performance of a business entity (as shareholder, customer, or employee), the actions of a public organization such as government, non-government and semi-government departments), the decisions of a community (on issues such as residential, education, safety, and public transport alternatives) or the organization of special interest group activities (including arts, hobbies, sports and recreation). However, only recently has the concept of stakeholders become popular amongst "academics and policymakers...[encouraging]... managers, stakeholders, and their representatives to develop [appropriate] practices" that encompass stakeholder opinions and direct organization interactions (Friedman \& Miles, 2006p. vii). Consulting with the full array of stakeholders in policy making has even become important for corporations as well as governments. The primary evidence of this is confirmed by the prevalent use of the term in the mass media - the Internet elicits thousands of entries under a 'stakeholders' search criteria, the introduction of stakeholder laws in many countries (Chen, Wu, Liu, Su, \& Chang, 2009; Donaldson \& Preston, 1995; Friedman \& Miles, 2006; Gelter, 2009), an emphasis on stakeholder management in corporate reporting (DSE, 2006) as well as publicity of newly introduced social responsibility programs (DEWR, 2007) in many government and corporate organizations. Stakeholders have traditionally been considered in terms of who they are (demographic attributes), what they want (main interests), and how they get what they want (nature and strength of influence) (Timur \& Getz, 2002). However, in the literature this simple explanation has developed into "hundreds of published definitions" (Miles, 2012) needed to cover a variety and nuances of stakeholder-organizational interactions. Even the more conservative writers still suggest around twenty descriptions are needed to adequately cover the range of primary notions of what a stakeholder is and does (BonnafousBoucher \& Porcher, 2010).

Given the growth of studies which focus on classifying or categorizing stakeholders, it is timely to review the conceptualization of stakeholders and use of stakeholder classification schemes to identify what might be research priorities in the short to medium term. The intent of this paper, therefore, is to review the utility of existing stakeholder classification schema for the identification of stakeholders from both a theoretical and practical viewpoint in public policy planning. This is presented in four parts: (1) a review of the conceptualization of stakeholders in relation to recent research, including a brief review of the principles of stakeholder theory; (2) an overview of the theoretical tenets and key dimensions of the various stakeholder classification schemes that have been developed; (3) the implications of stakeholder categorization in the public policy planning arena and the implications for a behaviourally based categorisation; and (4) some suggestions for future research efforts involving the development and application of stakeholder classification schemes.

\section{Stakeholders}

Although stakeholders are defined as people, groups of people, or individuals representing a body, group or organization with a stake or an interest in the activities or outcomes of the actions of others especially those of business concerns, not-for-profit organizations, government entities or government delegated operational departments, it is useful to organizations to attempt to distinguish between stakeholders differences, at least in their personal and behavioural characteristic.

The recognition that stakeholders are not just one homogenous group has been well established in the previous research into organizational activity and public policy development in particular. Consequently the classification of stakeholder types has been studied for many decades underpinned by attempts to describe stakeholders by attributes or attitudes. In these studies stakeholders are considered in terms of the theory (who should 
be a stakeholder) (Miles, 2012) or by empirical measures (who actually is a genuine stakeholder) (Fassin, 2012), which in turn requires an explanation of what a 'stake' might be, where such dimensions as the emotional, physical and monetary stake associated an individual or group can be considered.

Theoretically any person, group or organization with an interest in an issue, cause, or the consequences of an action is classified as a stakeholder and extended lists of who might be considered have been offered by many writers: Winn (2001, p.135) includes "employees, customers, shareholders, communities, environment, suppliers, public interest groups, media, and regulators"; Murphy and Murphy (2004) identified four distinct groups in the tourism community (1) customers (2) industry (3) residents and (4) government in their study of the future of a branded strata-title hotel accommodation; Dossman and Guilding (2006) included industry based stakeholders from banking, construction, real estate and hotel operations in their business of tourism study; Fassin (2012) simply described stakeholders as 'real, labelled or genuine' in an effort to show that not all stakeholders deserve full consideration by policy developers.

In a study on the impediments to adoption of alternative fuel vehicles stakeholders were grouped into some very broad categories: government, corporate, collaborators, competitors, activist and consumers (Byrne \& Polonsky, 2001). When considering sustainable tourism development, Cater writing in Hardy \& Beeton (2001, p.173) suggests there are "four loosely grouped stakeholder categories...host population, tourist guests, tourism organizations [operators and regulators] and the natural environment". The inclusion of the physical, intangible, inorganic and spiritual elements ('natural environment', 'the landscape', 'the climate') are a recent extension of the 'stakeholder interest' to include anything that might be affected or impacted by actions and decisions. However, generally the concept of including all stakeholders only extends its human representatives such as the media, politicians, environmental groups, general community, all levels of government, investors, suppliers, pressure groups, competitors, trade unions, professional associations and even academics (Charter, 1992).

Here we must therefore ask: 'Are all these people practicing stakeholders with a legitimate stake in the activity of the organization?' If these people show no interest in the issue at hand or under discussion does that make them any less of a stakeholder? Should they still be considered and probed for opinion or statement on policy issues? These questions have all been addressed to some degree in the literature pertaining to stakeholders in public policy development which generally describes or classifies stakeholders in such a way to highlight even minor or slight differences. It is most evident here that if a person or group of people can have a demonstrable and justifiable interest in the activities of an organization then they can be regarded as stakeholders and the organization should consider building relationships with them. No longer is it acceptable to try to counter or suppress stakeholder opinion or argument. Writers in the closing decades of the twentieth century stress the importance of creating a relationship with stakeholders that encompasses mutual trust and cooperation no matter how slight their involvement might be (Clarkson, 1995; Donaldson \& Preston, 1995; Freeman, 1984; Getz \& Jamal, 1994; Hoffman, Boal, \& Robinson, 2002; Jones \& Wicks, 1999).

There have been many thousands of projects reported in the government sector involving stakeholders and the selection of groups or individuals to be considered as stakeholders is usually based on a pre-set selection criteria, often fixed by the authority or the business conducting the consultation. Here the literature offers long lists of groups of people, organizations and even individuals to be considered as stakeholders in the consultation process with the implication developing that everyone, everywhere always stands to be affected in an interconnected and globalized world (Murphy et al., 2005; Polonsky, 1995; Smith \& Fischbacher, 2005; Waxenberger \& Spence, 2003). Theoretically most writers and practitioners return to Freeman's (1984) definition of stakeholders to determine who should be included - however the scope is set 
to capture all the people who may have an interest or be impacted in today's multidimensional strategy development or complex policy planning processes, where issues encompassed may include the environment, development, sustainability, economic viability and community values. This calls for more than just defining stakeholders and some writers have attempted to segment or classify operational differences in stakeholders' behaviour.

\section{Stakeholder classification schemes}

Defining and classifying stakeholders is a challenge for governments and private enterprise alike and there are many approaches to segmenting stakeholders. Most of the literature concentrates on variations of the following three approaches: Primary and Secondary; Voluntary and Involuntary; and Normative, Instrumental and Descriptive. A fourth approach that is far less widely discussed considers Stakeholder Behaviour in terms of process commitment and reaction to the final outcomes.

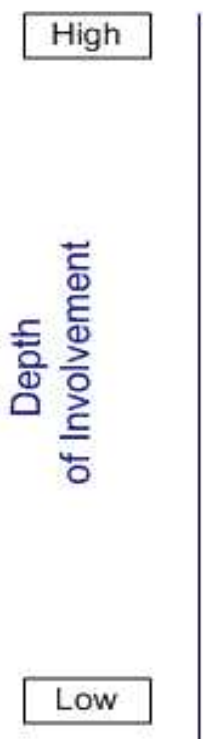

Low

\section{SECONDARY}

\section{Primary and Secondary Stakeholders}

Most writers generally agree that the main stakeholders, often referred to as the primary or direct stakeholders, are shareholders, customers, employees and suppliers. An organization would find it difficult to remain viable without its primary stakeholders (Cassidy \& Guilding, 2006; Clarkson, 1995). There is a high level of involvement and interactivity between primary stakeholders and the organization (Merrilees, Getz, \& O'Brien, 2005), however there is also a strong recognition of what are termed secondary or subsequent stakeholders (Winn, 2001), and whilst their effect or the effect on them is acknowledged, these stakeholders may not be closely engaged in the business of the organization (Merrilees, et al., 2005). Secondary stakeholders may include more than just individuals; organizations such as NGOs, activist groups, consumer lobbies, local communities and semi-government authorities can all be considered (Charter, 1992; Clement, 2005). The distinction between primary and secondary stakeholders is made on the basis

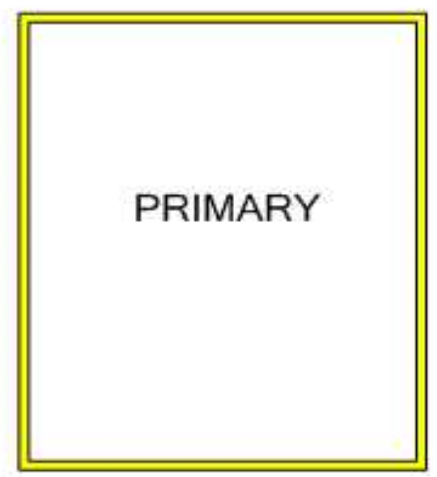


of their involvement and the importance their contribution to policy planning activities might be expected to have on them. This distinction between these roles is shown in Figure 1.

There is another group of stakeholders who belong in the secondary stakeholder category but may be worthy of their own classification these are fringe stakeholders, often considered as part of the activist group but are more typically the forgotten (the illiterate, the poor, the seemingly powerless), and forgetting these stakeholders can frequently be to the chagrin of the organizations as their interests are often raised by others more closely involved in the issue. For example, fringe stakeholders can affect change, and one case cited regularly in the literature concerns the hostile response from small farmers in India towards Monsanto's attempt to commercialize GMO techniques by incorporating seed sterilization technology in its proprietary insect and mould resistant seedgrain products, a situation which these farmers feared would make it impossible for them to grow future crops from the collection of their own grain seeds. A negative reaction worldwide forced Monsanto to abandon the technology (Clement, 2005; Kotler \& Keller, 2006).

\section{Voluntary and Involuntary Stakeholders}

Lorca and Garcia-Diez (2004) and Cooper (2003) identify two types of stakeholders, voluntary and involuntary. The voluntary stakeholders are the traditionally accepted groups, shareholders, employees, customers, and suppliers, the involuntary stakeholders are drawn from those with no direct link to the organization and who might reasonably expect to have no change in their lives whether the organization exists or does not. However, this can change dramatically if involuntary stakeholders are negatively affected by the actions of organization as it goes about its objectives to satisfy the voluntary stakeholders. Whilst voluntary stakeholders are easy to identify this is not so for involuntary ones. Figure 2 demonstrates this relationship by considering the relationship between the importance their contribution might have on the outcomes in comparison to the depth of involvement that the stakeholder takes within the consultation and discussion process in which the initiating agency develops a dialogue

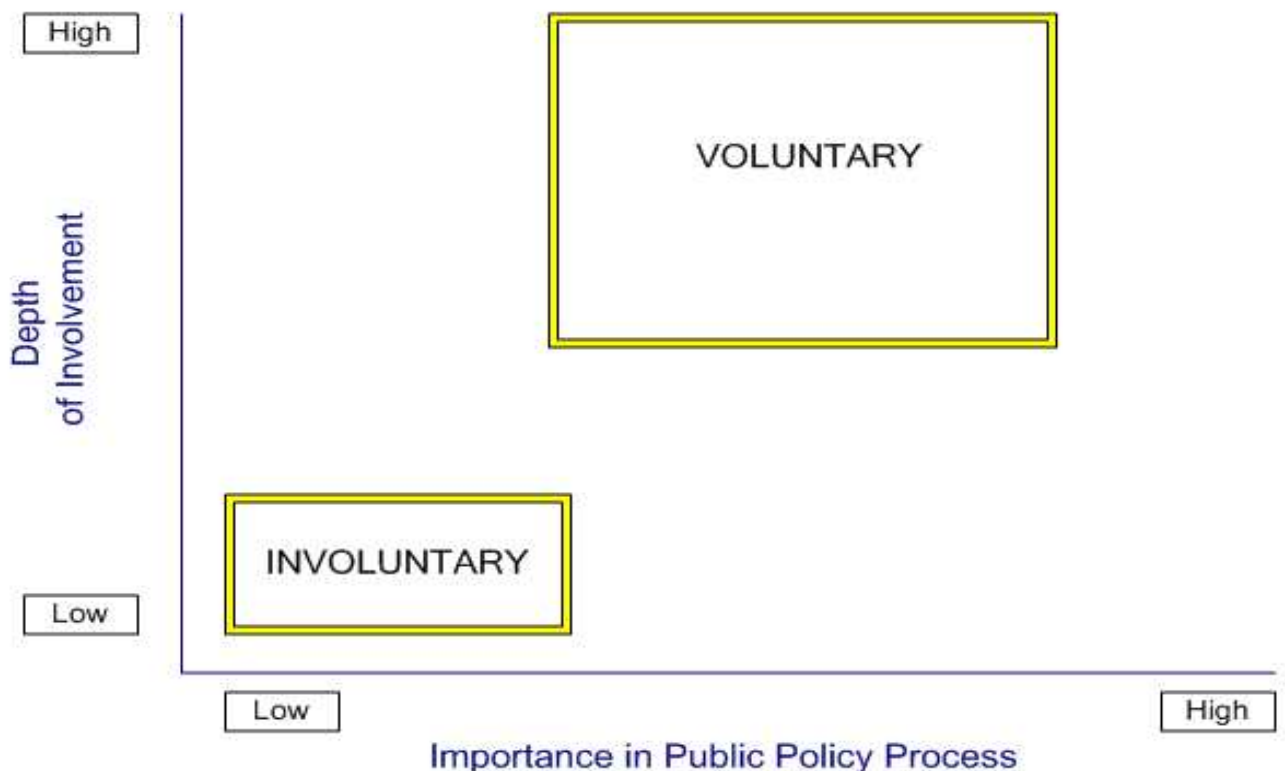

Figure 2. The Voluntary and Involuntary Typology of Stakeholder Interaction 
with those stakeholders that demonstrate a high degree of interest.

Cooper (2003, p.233) describes involuntary stakeholders as "individuals, communities, ecological environments, and future generations" who have not chosen to enter a relationship with the organization or may yet to be affected by the organization's activities, as in the case of future generations, who are unable to avoid the relationship because they will be impacted by the organization at a subsequent time. An example of a situation affecting an involuntary stakeholder in a more short-term scenario might be that a major tourism development is planned in a Region A, which has no direct impact on the business operators or residents of an adjoining area Region B. However, the development will impact on arterial road access and infrastructure so the business operators and residents in Region B, who need to pass the development site in their daily travel, are thus affected such that they become involuntary stakeholders in the tourism development outcome.

\section{Normative, Instrumental, Descriptive}

Within the considerable body of work on stakeholder theory the most often cited categorization model is that of normative, instrumental, and descriptive (Figure 3) with variations on this theme also offered by a numerous other researchers. However, these three descriptors relate to the study of the management of behaviour with regard to stakeholder's actions as opposed to the behaviour of stakeholders within interaction or consultation processes. Normative research focuses on the moral and social obligations of managers to behave in an ethical manner towards stakeholders, instrumental describes how organizations pursue their interests and improve performance through managing their relationships with stakeholders, and descriptive considers the actual behaviour of managers, their organizations and the stakeholders involved. For the latter the identification and categorization of stakeholders becomes just one part of the issue (Butterfield, Reed, \& Lemak, 2004; Cooper, 2003; Donaldson \& Preston, 1995; Friedman \& Miles, 2004, 2006). The normative approach to stakeholder theory is the most often cited in literature and indeed in the media in general (good corporate governance, good corporate citizen, ethical corporate behaviour), as it is based on the view that an organization has moral obligations towards its externalities specifically including its stakeholders (Byrd, Cardenas, \& Greenwood, 2008; Cooper, 2003; Donaldson \& Preston, 1995; Frooman, 1999; Phillips, 1997). It effectively describes "how firms should behave" (Donaldson \& Preston, 1995; Laplume, Sonpar, \& Litz, 2008, p.1159). As a consequence, the stakeholders of the 'general public' have come to have high expectations of business and especially the "multinational corporations when it comes to respecting the rights of people world-wide and preserving the environment for [future] generations" (Van de Ven, 2005, p.49). It is argued that organizations have a moral obligation to engage in activities that result in social betterment (Rowley, 1998) and that "all stakeholders should be treated with proper respect and consideration" (Timur \& Getz, 2002, p.197).

The instrumental approach involves focusing on how organizations pursue their interests, the impact stakeholders have on an organization and how these can be managed to meet not only the organization's specific requirements but also those of the stakeholders (Antonacopoulou \& Meric, 2005). This approach says "if managers treat stakeholders in line with the 'stakeholder concept' the organization will be more successful and sustainable" (Friedman \& Miles, 2006, p.2; Reed, 1999), and "it establishes a framework [in which] stakeholder management and achievement of corporate goals are examined" (Timur \& Getz, 2002, p.198). There is also a legal, or instrumental recognition that powerful stakeholders are critical to a firm's success (Reed, 1999). Although this idea might be essentially theoretical it is still accepted that management does need to consider stakeholders opinions in order to achieve its goals and to achieve an acceptable outcome where the organization must adopt principles and practices that are commensurate with its stakeholders' desires (Clarkson, 1995). 


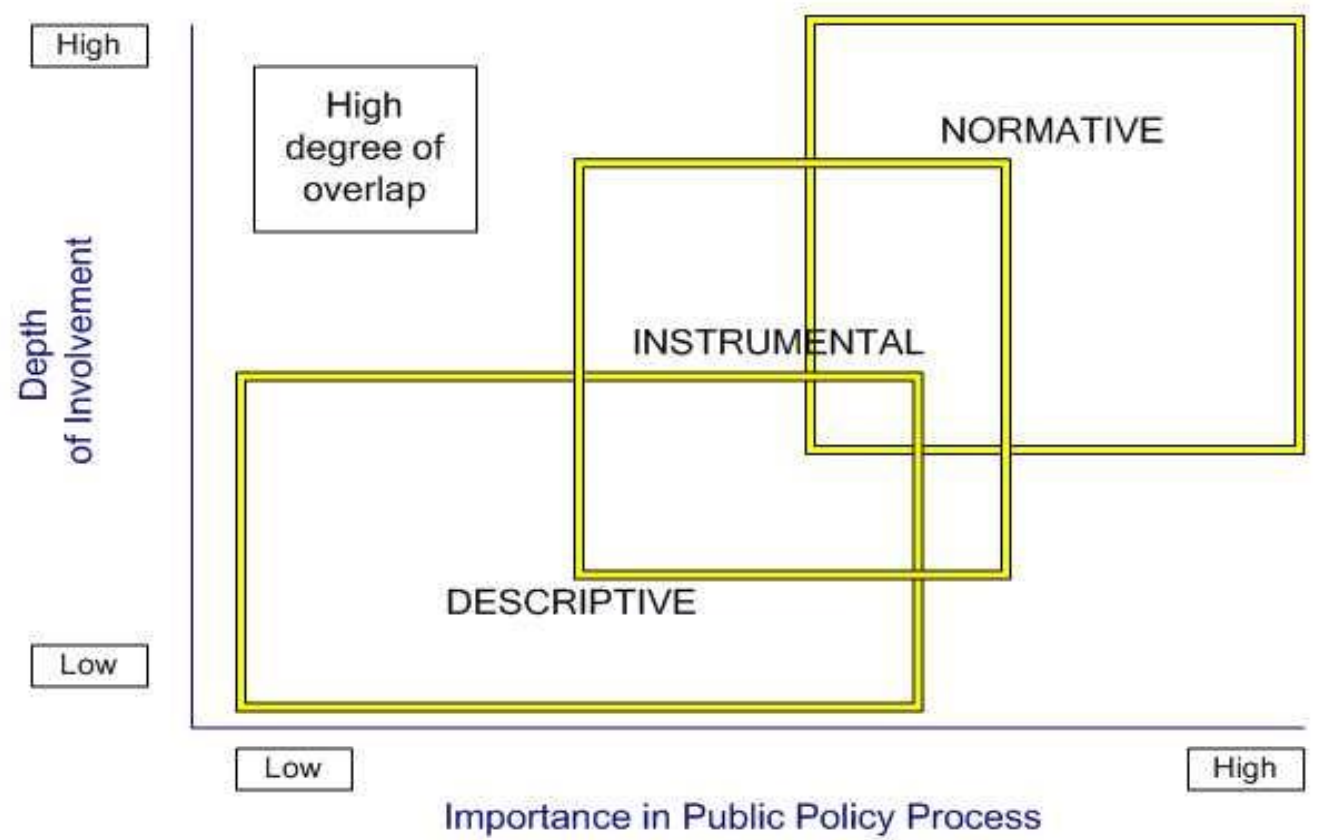

Figure 3. The Normative, Instrumental and Descriptive Typology

Descriptive stakeholder theory is an empirical approach to stakeholder analysis as it involves describing specific corporate characteristics and the behavioural interaction of the stakeholders in their relationship to the organization (Butterfield, et al., 2004; Egels, 2005), or may simply be stated as "how firms behave" in dealing with society, government and institutions (Laplume, et al., 2008, p.1159).

Although stakeholders may be referred to as exhibiting normative, instrumental and descriptive behaviour these tend to have been used more for guidance on how organizations should behave from a prescriptive perspective than describing stakeholder behaviour in interaction processes, a factor that is particularly relevant in the area of public policy planning.

\section{Stakeholder Behaviour Categorisation}

The fourth way of understanding the organization-stakeholder interaction was originally put forward by Polonsky, Schuppisser and Beldona (2002) who focused on the actions of the stakeholders and identified five behaviour groups (allied, cooperative, neutral, competitive and threatening). It is a multistakeholder approach which has not been generally cited in the literature, although some writers have alluded that these relationships may exist between different groups (Grossi, 2003; Munilla \& Miles, 2005). The identification of these five behaviour groups can form the basis of a multi-stakeholder approach to consultation and also to analysing existing stakeholder behaviour and relationships. Of particular importance is the dynamics of the interaction between organization and stakeholders. This can be seen in movement between stakeholder categories as relationships change during the consultation and interaction process that is a fundamental part of most modern public-policy formulation processes. It is seen in the stakeholders becoming stronger or weaker in influence and less or more committed in enthusiasm, or choosing to become uncooperative or even withdrawing from the consultation process all together.

All these approaches are summarised in Table 1 with an addition of the policy implications that are attached. 
Developing a new typology for a behavioural classification of stakeholders using the case of tourism public policy planning in the snow sports industry.

Table 1. Standard stakeholder classification schemes

\begin{tabular}{|c|c|c|c|}
\hline $\begin{array}{l}\text { Stakeholder } \\
\text { Classification }\end{array}$ & Stakeholder Description & Reference & $\begin{array}{l}\text { Public Policy Usage and } \\
\text { Implications }\end{array}$ \\
\hline Primary & $\begin{array}{l}\text { Shareholders; Customers; } \\
\text { Employees; Suppliers. }\end{array}$ & \multirow{2}{*}{$\begin{array}{l}\text { (Cassidy \& Guilding, 2006; } \\
\text { Charter, 1992; Clarkson, } \\
\text { 1995; Clement, 2005; } \\
\text { Friedman \& Miles, 2006; } \\
\text { Gibson, 2000; Merrilees et } \\
\text { al., 2005; Winn, 2001) }\end{array}$} & \multirow[t]{2}{*}{$\begin{array}{l}\text { Simple categories, useful in } \\
\text { survey research selection }\end{array}$} \\
\hline Secondary & $\begin{array}{l}\text { NGOs; Activists; Communities; } \\
\text { Governments (may also be } \\
\text { primary). }\end{array}$ & & \\
\hline Voluntary & $\begin{array}{l}\text { Shareholders; Customers; } \\
\text { Employees; Suppliers. }\end{array}$ & \multirow[t]{2}{*}{$\begin{array}{l}\text { (Cooper, 2003; Lorca \& } \\
\text { García-Diez, 2004) }\end{array}$} & \multirow{2}{*}{$\begin{array}{l}\text { Minor consideration of } \\
\text { broader interests. Useful in } \\
\text { selecting main group. Not } \\
\text { useful in planning actions. }\end{array}$} \\
\hline Involuntary & $\begin{array}{l}\text { No direct link but could be } \\
\text { affected (usually negatively) }\end{array}$ & & \\
\hline Normative & $\begin{array}{l}\text { Managing moral obligations } \\
\text { towards stakeholders. }\end{array}$ & \multirow{3}{*}{$\begin{array}{l}\text { (Antonacopoulou \& Meric, } \\
\text { 2005; Bonnafous-Boucher } \\
\text { \& Porcher, 2010; } \\
\text { Butterfield et al., 2004; } \\
\text { Cooper, 2003; d'Angella \& } \\
\text { Go, 2008; Donaldson \& } \\
\text { Preston, 1995; Egels, } \\
\text { 2005; Friedman \& Miles, } \\
\text { 2004, 2006; Laplume et al., } \\
\text { 2008; Mitchell, Agle, \& } \\
\text { Wood, 1997; Rowley, } \\
\text { 1998; Van de Ven, 2005) }\end{array}$} & \multirow{3}{*}{$\begin{array}{l}\text { Operational perceptive } \\
\text { from the organization and } \\
\text { its dealings with the public. } \\
\text { Internal management tool. }\end{array}$} \\
\hline Instrumental & $\begin{array}{l}\text { Managing stakeholders influence } \\
\text { on the organization. }\end{array}$ & & \\
\hline Descriptive & $\begin{array}{l}\text { Describing relationship with } \\
\text { stakeholders. }\end{array}$ & & \\
\hline Allied & $\begin{array}{l}\text { An understanding that the welfare } \\
\text { of each stakeholder is bound } \\
\text { together. }\end{array}$ & \multirow[t]{5}{*}{$\begin{array}{l}\text { (Grossi, 2003; Munilla \& } \\
\text { Miles, 2005; Polonsky et } \\
\text { al., 2002) }\end{array}$} & \multirow{5}{*}{$\begin{array}{l}\text { Develops attitudinal groups } \\
\text { and guides managerial } \\
\text { activity in involvement and } \\
\text { communication. Useful for } \\
\text { complex public orientated } \\
\text { interventions where } \\
\text { conflicting ideas will be } \\
\text { evident in the community. }\end{array}$} \\
\hline Cooperative & $\begin{array}{l}\text { Commitment is acknowledged, } \\
\text { but there is a reluctance to be too } \\
\text { specific about the nature of the } \\
\text { commitment/s. }\end{array}$ & & \\
\hline Neutral & $\begin{array}{l}\text { Stakeholders interact to achieve } \\
\text { goals, but perceive each other's } \\
\text { goals to be independent. }\end{array}$ & & \\
\hline Competitive & $\begin{array}{l}\text { Stakeholders strive to outperform } \\
\text { each other. }\end{array}$ & & \\
\hline Threatening & $\begin{array}{l}\text { Only one stakeholder in this } \\
\text { relationship can prevail. }\end{array}$ & & \\
\hline
\end{tabular}

\section{A New Typology: Allied, Guarded, Neutral and Disconnected}

The ski industry in Australia is one that has developed through the interaction and partnership of private business, skiing enthusiasts and Government agencies (SSA Report, 2008). This involvement in the industry 122 comes about through the use of public land, generally located within identified National Parks (NPWS, 2006), where the ski industry obtains leases and rights of use from the relevant managing authorities (Murphy, 2008). As Tomsett (2009) has described, this is quite different from the development of the snow 


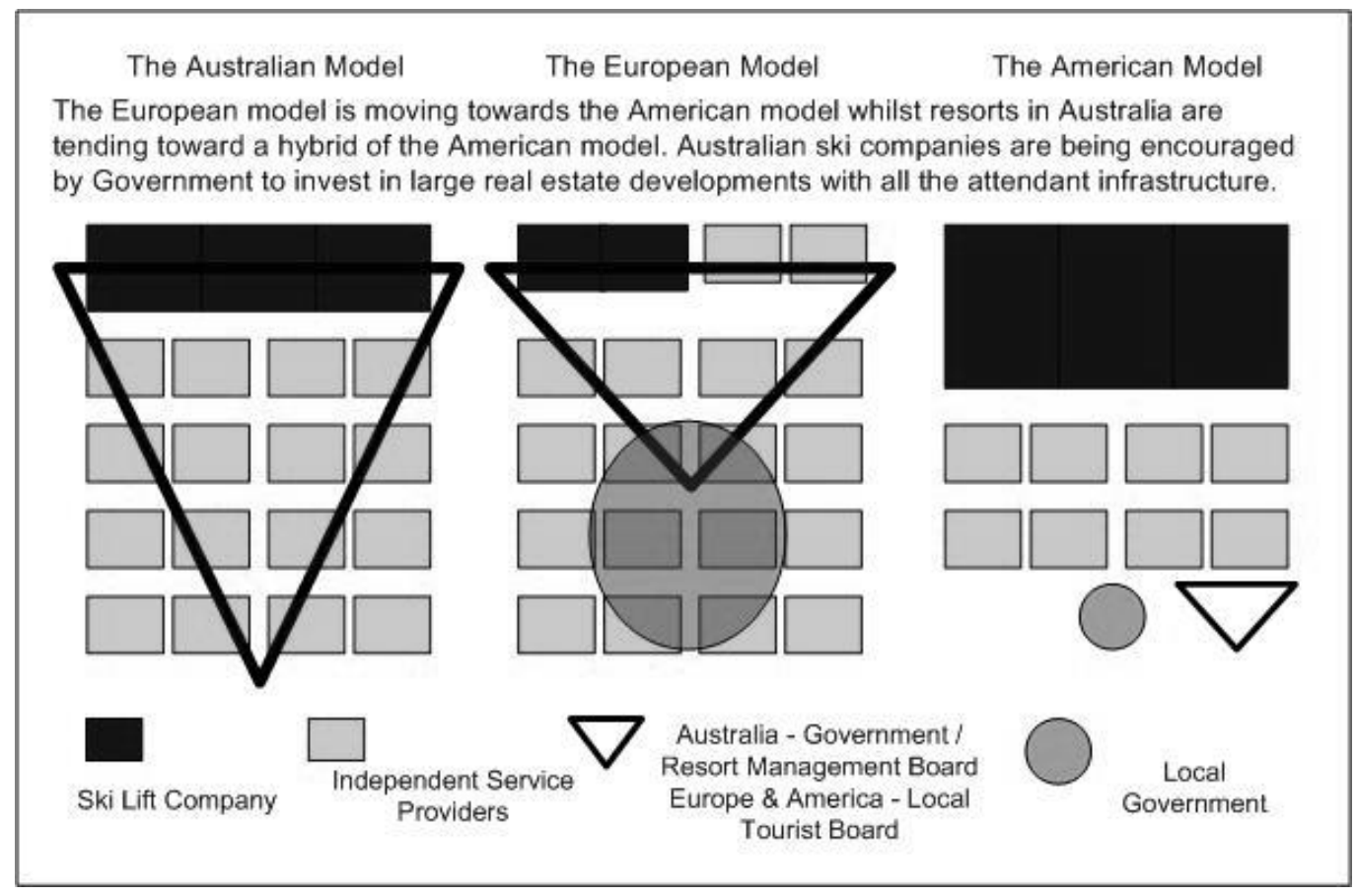

Source: Tomsett P. in Murphy “The Business of Resort Management” (Murphy, 2008)

Figure 4. International Ski Resort Development Models

sports industry on other continents. The comparison of those approaches is shown in Figure 4, which demonstrates the differences between the European development through private ownership, the US development through private enterprise and the Australian approach through a managed interaction between government, public and private enterprise. It is in this Australian situation that the interaction and input from stakeholders becomes much more critical to devising the best and most acceptable tourism public policy development and management outcomes.

The strategic management process used in the State of Victoria involved the preparation of a comprehensive tourism plan (DSE, 2004) for the five major ski resort areas. First published in 2004 it has since seen a number of partial reviews and a full review (SSA Report, 2008) in 2012 when the plan currently in operation was developed (ARCC \& Tourism Victoria, 2013). The key feature of the process implemented by government through its agencies in the Alpine Resorts Co-ordinating Council (ARCC) and the State Services Authority (SSA) has been the contribution of stakeholders through meetings, research, forums and discussions.

The following analysis is based on the research conducted on the initial policy formulation (2004) for the future of the ski industry in the State of Victoria (Australia) and involved interviews with stakeholders to assess the nature of their interaction with policy makers and their opinions and attitudes to the planning document that was adopted (ARCC \& Tourism Victoria, 2013). This identified four groups defined by their behaviour in the consultation and their continuing commitment to the actions and outcomes of the plan itself. These were identified as 'allied, disconnected, neutral and guarded' segments (Figure 5).

As shown in Figure 5, the complex nature of most policy planning processes with various stakeholders representing a multitude of interests, as in tourism policy planning, confirms the most useful classification of stakeholders involvement and importance appears to be by the identification of behavioural groups (Polonsky, et al., 2002; 


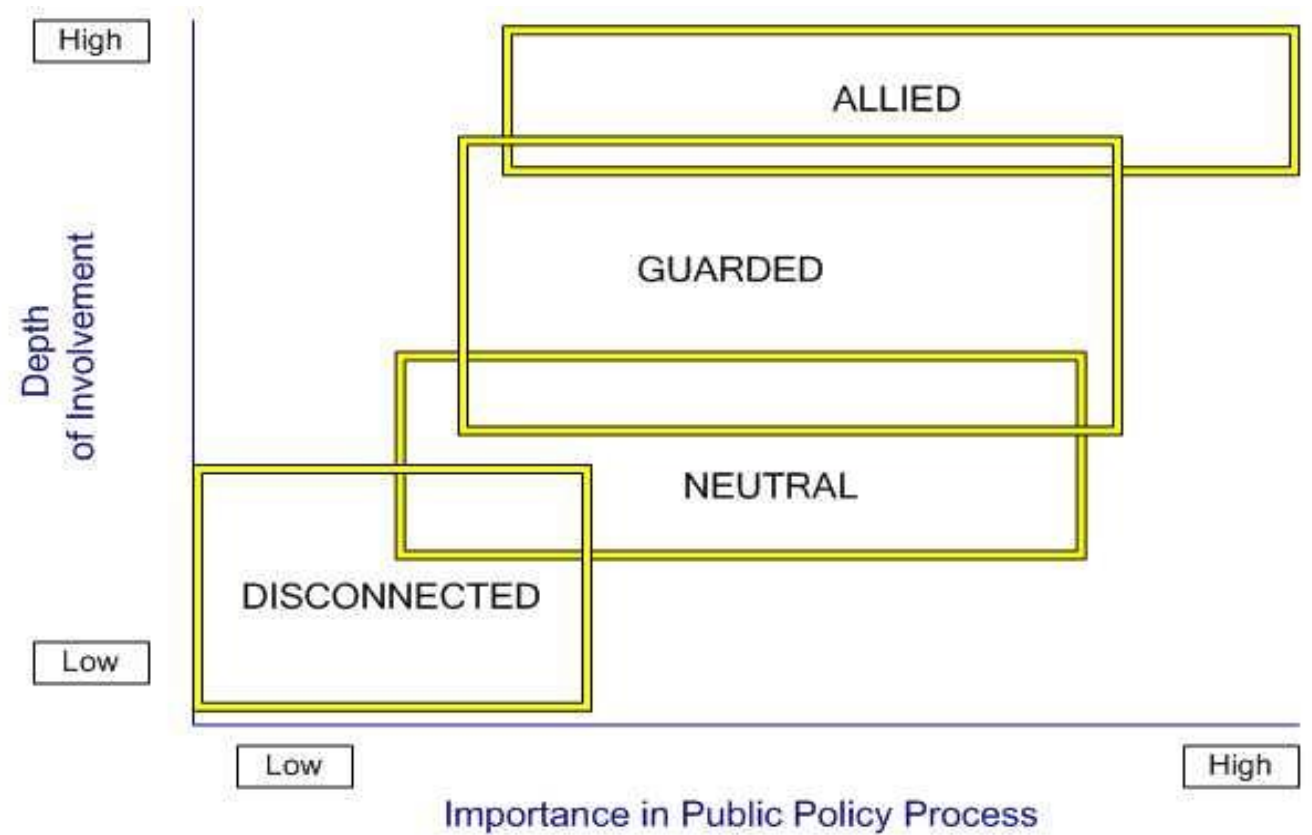

Figure 5. Allied, Guarded, Neutral and Disconnected Stakeholder Categories

Tomsett, 2009).

The 'allied' stakeholder has a vested interest in the outcome and tends to be a primary supplied of themes and approaches to public policy. They perceive that the outcome will be to their benefit and have confidence in the planning process outcomes to represent their opinions. Their behavioural status does not change during the consultation process and maintaining the 'allied position' is seen as ensuring favourable outcomes. The 'guarded' stakeholders tend to be anxious about the consultation process and expect the outcomes to favour those in the 'allied' category. Their involvement in the process is based on a 'hope' that alternative points of view will be recognised and will be a part of the final outcomes. The 'neutral' stakeholders feel they have a stake in the issue but often feel the deliberations in planning and the resulting outcomes will not have a major impact on them. They participate in the consultation process to be informed. The potential to convert this category into either allied or guarded is an outcome of the actions of the policy development group during the 124 consultation process. The 'disconnected' stakeholder, on the other hand, can be identified through 'their right to know'. They become involved to gain information and not necessarily to take action. They are not committed to consultation processes designed to collect their opinions but do claim their right to be given or supplied information on the development of the possible outcomes. The 'disconnected' category is unlikely to become more involved but can remain vocal with personal opinions of the process and its outcomes.

\section{Applying Stakeholder Theory to Tourism Public} Policy Planning

Behaviour groups provide the necessary scope to include all stakeholders no matter how peripheral they may seem to the policy under scrutiny, whether it is a planning issue to allow new infrastructure to be constructed or a complex strategy for a tourism area with a host of activities and issues affecting both the local community and the wider population where state and regional environmental, historical, cultural, indigenous and economic implications might be identified. In addition being able to 
Table 2. A dynamic outcome orientated stakeholder classification scheme

\begin{tabular}{|c|c|c|c|}
\hline $\begin{array}{l}\text { Stakeholder } \\
\text { Classification }\end{array}$ & Stakeholder Description & Reference & $\begin{array}{l}\text { Public Policy Usage and } \\
\text { Implications }\end{array}$ \\
\hline Allied & $\begin{array}{l}\text { Stakeholders do not change } \\
\text { behaviour. Remain allied to the } \\
\text { process, support the consultation } \\
\text { process, are committed to a } \\
\text { successful outcome. }\end{array}$ & \multirow{4}{*}{ (Tomsett, 2009) } & \multirow{4}{*}{$\begin{array}{l}\text { Dynamic and progressive } \\
\text { evaluation of contribution } \\
\text { process to public policy } \\
\text { development and guidance } \\
\text { to potential for reactions to } \\
\text { final public policy } \\
\text { implementation. } \\
\text { Useful when the process is } \\
\text { also attempting to share } \\
\text { information and come to } \\
\text { an agreement on the final } \\
\text { actions that should be } \\
\text { implemented. } \\
\text { This contains elements of } \\
\text { public relations, public } \\
\text { communication and } \\
\text { consensus in decision } \\
\text { making. }\end{array}$} \\
\hline Disconnected & $\begin{array}{l}\text { Stakeholders only interested in } \\
\text { personal issues, want their views } \\
\text { considered, and want to know } \\
\text { what is going on. Not committed } \\
\text { to consultation but do want a } \\
\text { successful outcome. }\end{array}$ & & \\
\hline Guarded & $\begin{array}{l}\text { This stakeholder is anxious, not } \\
\text { confident in the consultation } \\
\text { process and expects the } \\
\text { outcome to favour the } \\
\text { organisation or powerful } \\
\text { stakeholders are committed to } \\
\text { the process but doubt the } \\
\text { outcome will be successful. }\end{array}$ & & \\
\hline Neutral & $\begin{array}{l}\text { All those stakeholders identified } \\
\text { as having a stake in the issue } \\
\text { under investigation or discussion, } \\
\text { not committed to the consultation } \\
\text { process and have no interest in } \\
\text { the outcome, unless it affects } \\
\text { them, which may not be } \\
\text { recognized until after the } \\
\text { outcome has been adopted. }\end{array}$ & & \\
\hline
\end{tabular}

classify and understand stakeholders in terms of their behaviour is of enormous benefit to planners and governments charged with the responsibility of conducting consultation processes as it can prevent misunderstandings amongst stakeholder participants. Those conducting the consultation may be able to value the stakeholders' contributions by understanding their reasons for being involved and motivations that stem from their underlying beliefs and attitudes.

It is important to note that in his seminal work on stakeholder theory Freeman (1984) expressed the view that stakeholders could be considered 'cooperative' and representing an opportunity for management in contrast to being viewed as 'competitive' and in which case they would be a threat to management's plans and actions. Stakeholders are more likely to impact the organization's decision making than the general public and to this end Clarkson (1995) suggested that organizations would be wiser to concentrate on stakeholders' specific issues rather than the more general or broader social issues.

The role and classification of stakeholders has become increasingly important for the public policy planning process, it has been enshrined in legislation in many countries and is central to the move toward sustainable development in democratically, industrially and economically advanced nations (Bonnafous-Boucher \& Porcher, 2010; Chen, et al., 2009) and the public or community expect to be consulted. There are also overwhelming benefits for policy planners to openly engage stakeholders; even strictly economic issues will eventually become political in nature as the solutions in public 
Developing a new typology for a behavioural classification of stakeholders using the case of tourism public policy planning in the snow sports industry.

policy generally "will affect how the people live together" (Chen et al., 2009).

Public policy planning can only benefit from the work done by stakeholder researchers as the outcomes offer planners a very real understanding of the dynamics of public consultation and higher potential for success in the implementation of plans assessed and agreed to by stakeholders (Chen, et al., 2009).

\section{Conclusions and Future Research}

Tables 1 and 2 have shown summaries of the key features of each of the methods of classifying stakeholders discussed here. Each provides a broad scope for describing the diverse nature of, and relationships between stakeholders in the development and implementation of complex strategies that combine all the elements of stakeholder theory, including stakeholder relationships and stakeholder management raised by various writers over the last three decades.

The significance of the stakeholder as a concept in the formation and evaluation of public policy continues to increase throughout the democratic world. The differences in attitudes, needs and opinions and their related behaviour are becoming more critical to policy makers as the recognition of small and minority groups in that decision making is more widely acknowledged by politicians, legislators, judiciary, business leaders, and the community. Consequently, continuing to identify stakeholders, understand the differences between individuals and groups, mapping stakeholder behaviour and exploring how their behaviour might change in the future, offers many opportunities for further research. It is recommended that the dynamics of the behavioural classification schema in terms of the characteristics of stakeholders is essential to better understand and proactively engaging them in public policy planning. This is also an issue for newer democracies where talking directly with stakeholders across cultural divides within multi-cultural societies, like many European countries especially those striving for EU membership or in the more traditional cultures of East Asia, will extend our knowledge of how to successfully engage stakeholders and develop solutions that truly address the desires of all interested parties.

\section{References}

Antonacopoulou, E. P., \& Meric, J. (2005). A critique of stakeholder theory: management science or a sophisticated ideology of control? Corporate Governance, 5(2), 22-33.

ARCC, \& Tourism Victoria. (2013). Draft Alpine Resorts Strategic Marketing Plan 20142018. Melbourne: Alpine Resorts Coordinating Council.

Bonnafous-Boucher, M., \& Porcher, S. (2010). Towards a stakeholder society: Stakeholder theory vs theory of civil society. European Management Review, 7, 205-216.

Butterfield, K. D., Reed, R., \& Lemak, D. J. (2004). An Inductive Model of Collaboration from the Stakeholder's Perspective. Business and Society, 43(2), 162-195.

Byrd, E. T., Cardenas, D. A., \& Greenwood, J. B. (2008). Factors of stakeholder understanding of tourism: The case of Eastern North Carolina. Tourism and Hospitality Research, 8(3), 192-204.

Byrne, M. R., \& Polonsky, M. J. (2001). Impediments to consumer adoption of sustainable transportation: Alternative fuel vehicles. International Journal of Operations \& Production Management, 21(12), 1521-1538.

Cassidy, K., \& Guilding, C. (2006). An Investigation of the Composition and Dynamics of the Strata Titled Tourism Accommodation Industry Using Stakeholder Theory. In G. B. O'Mahony \& P. A. Whitelaw (Eds.), CAUTHE: Proceedings of the 16th Annual Conference (Vol. CD-ROM, pp. 12281231): Victoria University Melbourne 69 February.

Charter, M. (Ed.). (1992). Greener Marketing: A Responsible Approach to Business. Sheffield: Greenleaf Publishing.

Chen, C.-H., Wu, R.-S., Liu, W.-L., Su, W.-R., \& Chang, Y.-M. (2009). Development of a Methodology for Strategic Environmental Assessment: Application to the Assessment of Golf Course 
Installation Policy in Taiwan. Environmental Management, 43(1), 166-188.

Clarkson, M. B. E. (1995). A Stakeholder Framework for analyzing and evaluating corporate social performance. Academy of Management Review, 20, 92-117.

Clement, R. W. (2005). The lessons from Stakeholder theory for U.S. business leaders. Business Horizons, 48(3), 255264.

Cooper, S. M. (2003). Stakeholder communication and the Internet in UK electricity companies. Managerial Auditing Journal, 18(3), 232-243.

d'Angella, F., \& Go, F. M. (2008). Tale of two cities' collaborative tourism marketing: Towards a theory of destination stakeholder assessment. Tourism Management, 30(3), 429-440.

DEWR. (2007). Department of Environment and Water Resources http://www.environment.gov.au/settlem ents/industry/corporate/reporting (Accessed on 09 July 2007)

Donaldson, T., \& Preston, L. (1995). The Stakeholder Theory of the Corporation: Concepts, Evidence, Implications. Academy of Management Review, 20, 65-91.

DSE. (2004). Alpine Resorts 2020 Strategy. Melbourne: State Government of Victoria.

DSE. (2006). Stakeholder relations and community consultation: Department of Sustainability and Environment URL:http://www.dse.vic.gov.au/DSE/nr enpl.nsf/LinkView/5F514520B3BE6FF9 CA256E7B002C0AF8C4EB543DC77A 77864A256DEA002C5760 (Accessed on 01 September 2006)

Egels, N. (2005). CSR in electrification of rural Africa: the case of ABB in Tanzania. The Journal of Corporate Citizenship(18), 75-85.

Fassin, Y. (2012). Stakeholder management, reciprocity and stakeholder responsibility. Journal of Business Ethics, 109(1), 83-96.

Freeman, R. E. (1984). Strategic Management: A Stakeholder Approach. Boston: Pitman Publishing Inc.
Friedman, A. L., \& Miles, S. (2004). Stakeholder theory and communication practice. Journal of Communication Management, 9(1), 95-97.

Friedman, A. L., \& Miles, S. (2006). Stakeholders Theory and Practice. New York: Oxford University Press.

Frooman, J. (1999). Stakeholder influence strategies. Academy of Management Journal, 24, 191-205.

Gelter, M. (2009). The dark side of shareholder influence: toward a Holdup theory of stakeholders in comparative corporate governance. Harvard International Law Journal, 50(1), 129-194.

Getz, D., \& Jamal, T. B. (1994). The environment-community symbiosis: a case for collaborative tourism planning. Journal of Sustainable Tourism, 2(3), 152-173.

Gibson, K. (2000). The moral basis of stakeholder theory. Journal of Business Ethics, 26(3), 245-257.

Grossi, I. (2003). Stakeholder Analysis in the Context of the Lean Enterprise Master of Science in Engineering and Management, Massachusetts Institute of Technology, Boston. URL: http://dspace.mit.edu/handle/1721.1/34 797 (Accessed on 02 November 2009)

Hardy, A. L., \& Beeton, R. J. S. (2001). Sustainable tourism or maintainable tourism: managing resources for more than average outcomes. Journal of Sustainable Tourism, 9(3), 168-192.

Hoffman, J. J., Boal, K. B., \& Robinson, D. F. (2002). Valued stakeholders or unwanted stepchildren?--A stepfamily theory regarding physician group divestitures. Health Care Management Review, 27(2), 80-91.

Jones, T. M., \& Wicks, A. C. (1999). Convergent Stakeholder Theory Academy of Management Review 24, 206-221.

Kotler, P., \& Keller, K. L. (2006). Marketing Management, (12th ed.). Upper Saddle River, NJ: Prentice-Hall.

Laplume, A. O., Sonpar, K., \& Litz, R. A. (2008). Stakeholder theory: reviewing a theory that moves us. Journal of Management, 34(6), 1152-1189. 
Lorca, P., \& García-Diez, J. (2004). The relation between firm survival and the achievement of balance among its stakeholders: an analysis. International Journal of Management, 21(1), 93-99.

Merrilees, B., Getz, D., \& O'Brien, D. (2005). Marketing stakeholder analysis: branding the Brisbane Goodwill Games. European Journal of Marketing, 39(9/10), 1060-1077.

Miles, S. (2012). Stakeholder: Essentially Contested or Just Confused? Journal of Business Ethics, 108(3), 285-298.

Mitchell, R. K., Agle, B. R., \& Wood, D. J. (1997). Toward a theory of stakeholder identification and salience: defining the principle of who and what really counts. The Academy of Management Review, 22(4), 853-886.

Munilla, L. S., \& Miles, M. P. (2005). The Corporate Social Responsibility Continuum as a Component of Stakeholder Theory. Business and Society Review, 110(4), 371-387.

Murphy, B., Maguiness, P., Pescott, C., Wislang, S., Ma, J., \& Wang, R. (2005). Stakeholder perceptions presage holistic stakeholder relationship marketing performance. European Journal of Marketing, 39(9/10), 10491059.

Murphy, P. E. (2008). The Business of Resort Management. Oxford, UK: ButterworthHeinemann.

Murphy, P. E., \& Murphy, A. E. (2004). Strategic Management for Tourism Communities: Bridging the Gaps. Clevedon: Channel View Publications.

NPWS. (2006). 2006 Plan of Management Koscuiszko National Park. Sydney South: NSW National Parks and Wildlife Service.

Phillips, R. A. (1997). Stakeholder theory and a principle of fairness. Business Ethics Quarterly, 7(1), 51-66.
Polonsky, M. J. (1995). A stakeholder theory approach to designing environmental marketing strategy. Journal of Business \& Industrial Marketing, 10(3), 29-46.

Polonsky, M. J., Schuppisser, D. S. W., \& Beldona, S. (2002). A Stakeholder perspective for analyzing marketing relationships. Journal of Market Focused Management, 5(2), 109-126.

Reed, D. (1999). Stakeholder management theory: a critical theory perspective. Business Ethics Quarterly, 9(3), 453483.

Rowley, T. J. (1998). A normative justification for stakeholder theory. Business and Society, 37(1), 105-107.

Smith, A. M., \& Fischbacher, M. (2005). New service development: a stakeholder perspective. European Journal of Marketing, 39(9/10), 1025-1048.

SSA Report. (2008). Review of Alpine Resort Areas 2006-7: Final Report. Melbourne: State Services Authority, Vic.

Timur, S., \& Getz, D. (2002). Applying Stakeholder Theory to The Implementation of Sustainable Urban Tourism. Paper presented at the City Tourism 2002, Vienna, Austria.

Tomsett, P. M. (2009). Analysis of Changing Stakeholder Behaviour: Case Study of the Consultation Process for the Victorian Alpine Resorts 2020 Strategy. Doctor of Philosophy, La Trobe University, Melbourne, Australia.

Van de Ven, B. (2005). Human rights as a normative basis for stakeholder legitimacy. Corporate Governance, 5(2), 48-59.

Waxenberger, B., \& Spence, L. J. (2003). Reinterpretation of a metaphor: from stakes to claims. Strategic Change, 12(5), 239-249.

Winn, M. I. (2001). Building stakeholder theory with a decision modeling methodology. Business and Society, 40(2), 133-166. 